\title{
GIS-based mapping and assessment of noise pollution in Safranbolu, Karabuk, Turkey
}

\author{
Ertugrul Esmeray $^{1}$ (D) Sercan Eren ${ }^{1}$
}

Received: 13 January 2020 / Accepted: 17 February 2021 / Published online: 27 February 2021 (c) The Author(s), under exclusive licence to Springer Nature B.V. part of Springer Nature 2021

\begin{abstract}
In this study, it is aimed to determine and map the noise pollution levels in Safranbolu District Center, especially in the regions where motor vehicle and/or pedestrian traffic is intense. Forty-seven measurement points were selected for noise level measurements at the district center. Measurements were conducted at morning (8 a.m.-10 a.m.), lunchtime (12 p.m.-2 p.m.) and evening (6 p.m.-8 p.m.) hours of weekdays and weekends throughout the seasons of summer 2017 and winter 2018. The summer season weekdays noise level ranges from 41.3 to $71.2 \mathrm{dBA}$ in the morning period, 40 to $71.2 \mathrm{dBA}$ in the noon period and 40.6 to $73.1 \mathrm{dBA}$ in the evening. The summer season weekend noise level ranges from 45.3 to $69.1 \mathrm{dBA}$ in the morning period, 44.7 to $71.4 \mathrm{dBA}$ in the noon period and 41.6 to $70.9 \mathrm{dBA}$ in the evening. The result showed that the level of summer season weekday and weekend noise pollution in the morning, noon and evening is close to each other. In addition, the winter season weekdays noise level ranges from 32.3 to $68.5 \mathrm{dBA}$ in the morning period, 30.8 to $73.3 \mathrm{dBA}$ in the noon period and 37.4 to $72.9 \mathrm{dBA}$ in the evening. The winter season weekend noise level ranges from 37.2 to $65.8 \mathrm{dBA}$ in the morning period, 40 to $71.3 \mathrm{dBA}$ in the noon period and 40.5 to $69.7 \mathrm{dBA}$ in the evening. The result showed that the level of winter season weekdays and weekend noise pollution in the noon is generally higher than morning and evening. The obtained data are compared with the limit values specified in the Environmental Hazard Assessment and Management Regulation. The hazardous noise level, which is considered as the threshold for causing physiological problems on humans, was determined to be exceeded at many locations. This situation may cause significant negative consequences on human health, quality of life and tourism sector. Obtained data were processed, and noise pollution levels for the city of Safranbolu were mapped using a geostatistical analysis software. In total, 16 noise pollution maps were drawn for different situations (e.g., weekdays, weekend, daytime, noon, night, summer season, winter season, etc.). Obtained noise level results demonstrate that the overall quality of the acoustic environment in our study area was medium level, which means that exposure to these levels over a long period can affect human health and quality of life. Finally, the results of a survey conducted as a part of this study were given, and possible measures and suggestions to reduce these noise levels in the district down to the desired limit values were discussed.
\end{abstract}

Keywords Noise pollution · GIS-based mapping · Safranbolu 


\section{Introduction}

Noise pollution is the whole of unwanted or harmful sounds that are in terms of health and quality of life, resulting from human activities. In recent years, excessive noise has also gained a different characteristic besides being a factor that causes discomfort. It is observed that when people are exposed to sound waves at high intensities for long periods of time, they lose their health (Kephalopoulos et al. 2014; Gupta et.al 2018; Kumar et al. 2018; Mehdi et al. 2018). Development of the transportation network, proliferation of motor vehicles, widespread mechanization and failures in protecting densely populated residential areas from noise due to unplanned rapid urbanization cause many problems in terms of public health. Noise pollution has been reported to be a major problem especially for those living in big cities (Bermúdez et al. 2019; Garg et al. 2017; Kalawapudi et al. 2020; Vladimir and Madalina 2019). Traffic, industry, construction, etc., in cities are the main source of noise pollution (Cueto et al. 2017; Kephalopoulos et al. 2014; Khodaei et al. 2009; Morel 2016; Morley et al. 2015; Yilmaz and Ozer 2005). Noise pollution has created a new working area for researchers, with the identification of noise pollution hazards on human health (Cueto et al. 2017; Majidi and Khosravi 2016). Many studies have shown that short- and long-term exposure to noise not only reduces human hearing, but also increases blood pressure, cardiovascular disease, anxiety and insomnia. Thus, noise exposure leads an increase in drug use and visits to hospitals (Farooqi et al. 2017). The noise caused by urban traffic can lead to increased heart diseases (Singh et al. 2018). Many academic studies showed that constant, variable and pulsed noise have negative effects on humans. The most harmful type of noise is the impact noise. The discomforts of the noise on humans are generally examined in four main groups: physical effects (ear problems, acoustic trauma); physiologically (blood pressure, circulatory, sleep disorder, respiration, acceleration, etc.); psychological effects (behavioral disorders, outburst of anger); and performance effects (inefficiency, concentration disturbance) (Garg et al. 2017; Singh et al. 2018; Farooqi 2017). Different kinds of problems that are caused by noise levels on humans are shown in Table 1.

Safranbolu is a city and a district center within the Karabük Province located in Western Black Sea Region of Turkey. Safranbolu is a popular tourist destination, and domestic and foreign visitors make a sizeable addition to the number of people present in the city, particularly, during the high season. A total of 68,440 people lives within the district borders (TUIK, 2019) and 315,842 tourists visited in the city in 2018 (Republic of Turkey Ministry of Culture and Tourism 2019). In addition, Safranbolu hosted about 76.000 domestic and foreign tourists with accommodation the first eight months of 2020 despite the COVID-19. In addition, Safranbolu hosted about 310,000 domestic and foreign tourists without accommodation on the same period despite COVID-19 (Ozler, 2020). The old town area of Safranbolu is in the list of UNESCO World Heritage sites since 1994 due

Table 1 Evaluation of noise levels (Anonymous, 1996)

\begin{tabular}{lll}
\hline Levels & Noise level dB(A) & Consequences \\
\hline 1.Level & $30-65$ & Confusion, discomfort, anger, sleep, etc., disorders \\
2.Level & $65-90$ & Physiological responses \\
3.Level & $90-120$ & Increased physiological responses, headaches \\
4.Level & $>120$ & Permanent damage to internal ear and balance deterioration \\
5.Level & $>140$ & Serious brain destruction \\
\hline
\end{tabular}


to its well-preserved houses dating back to eighteenth and nineteenth century. Therefore, noise pollution is of great importance for the economy and human health in this region. Furthermore, four faculties and two vocational schools affiliated to Karabük University are located within the city borders and students of these institutions cause a significant increase during most of the year (except summer months) in local population. The students mostly are not registered as residents of the city and hence not counted in census data of the city. Accordingly, the noise population generation potential in Safranbolu City is anticipated to be greater than other cities with comparable sizes.

Although Safranbolu is a world cultural heritage city and attracts many tourists, the environmental issues of the city that are fundamentally associated to tourism have not been studied scientifically at a sufficient level. Future studies on this subject are being planned by Republic of Turkey Ministry of Environment and Urbanisation; however, there are not enough available scientific data on this subject in the literature for the district of Safranbolu (Karabük Prov. Direct. of Environ. and Forestry 2008, 2017). Due to unavailable environmental data, the decision-making processes related to dealing with environmental problems are very difficult and costly for local authorities. Also, in Safranbolu District, noise pollution is one of the issues where there is a need to raise public awareness. This study aims to collect noise pollution data that can be accessed by local authorities to create policies; to raise public awareness about the risks of noise pollution; and to contribute to scientific literature about possible measures to alleviate noise pollution.

\section{Material and method}

In the district of Safranbolu, 47 different points were determined to measure noise levels and to create a noise map, especially to identify noise levels in touristic areas. The coordinates of these points were determined according to geographic coordinate system with Garmin Etrex 10 GPS device. CEM DT-8852 brand Type 1 sound meter is used for noise measurements. The sound meter was calibrated with the CEM SC-05 before the noise measurements. The maximum sound pressure level of the noise meter is $130 \mathrm{dBA}$, and it is capable of measuring noise levels ranging from 30 to $130 \mathrm{dBA}$.

Satellite images to be used in GIS-based mapping processes must be of high resolution in terms of accuracy. Therefore, all the high-resolution satellite imagery used in this study was captured in 2018 through Google Earth Software. (Google Earth 2018).

The method chosen for the measurements was determined by examining many similar studies in scientific literature. When these studies are investigated, it is seen that similar measurement methods and measurement time periods are used (Farooqi et al. 2017; Karakus and Yildız 2020; Kephalopoulos et al. 2014; Oguntunde et al. 2019; Rafael et al. 2015).

These 47 points were chosen to show the most accurate noise levels in the region. While determining the main measurement points in the study, the following criteria were taken into consideration.

- Creating proper placement density in different types of urban zones (most areas are "protected areas"; hence, measurement in residential areas was limited)

- Traffic density (main streets and roads in Safranbolu with heavy traffic)

- Touristic routes (pedestrian tourist traffic is an important source of noise)

- Shopping malls, bazaars and public markets that are popular among tourists and locals,

- University student dormitories, 
- Cafes and restaurants,

- Establishments where live music is played.

First, the coordinates of those 47 measurement points were confirmed via GPS. Noise measurements were made in the summer of 2017 and in the winter of 2018. A total of 500 measurements were carried out throughout in this study. For each week, measurements were taken on 2 days in the weekdays of the week and on two days on the weekends of the week at each location. For each day, 3 separate measurements were recorded during morning, noon and evening hours. The measurements were made on a tripod at a height of $1.5 \mathrm{~m}$ from the ground level. Noise measurements were carried out within the borders of the City of Safranbolu at locations which are visited by tourists, between 07:00 and 09:00 in the morning, 12:00 and 14:00 at around the noon and 18.00 and 20:00 in the evening. For measuring accuracy, a minimum of 15-min-long measurement was made at each location. The measurement device automatically determined the maximum and minimum values within the measured values, excluding outliners. In this way, data points created due to erroneous signals and extreme high/low signals during data recording were not saved in the device memory. Using this built-in feature of the device, a higher validity level was achieved for the calculated average value of the 15-min measurements.

There are various novel methods that are available for mapping, such as statistical models (e.g., inverse distance weighting (IDW), local polynomial interpolation (LPI), radial basis function (RBF), ordinary kriging (OK), and empirical Bayes kriging (EBK)) and machine learning models using neural networks. Each method has its own advantages and disadvantages (İmamoglu et al. 2016; Bhunia et al. 2018; Arseni et al. 2019). RBF is one of the most important methods that are used to find an optimal shape parameter. With this method, data of any size can be easily converted to nonlinear data of another dimension. There are many fields of applications for the RBF method in numerical analysis and statistics, such as machine learning, data mining, digital solution of partial differential equations, GIS-based mapping, geodesy, meteorology, etc. (Adhikary and Dash 2017; Mongillo, 2011). RBF was preferred as the interpolation method in this study. In the RBF method, the surface must pass through each measured sample value. This method consists of five different basis functions: (1) thin-plate spline; (2) spline with tension; (3) completely regularized spline; (4) multiquadric function; and (5) inverse multiquadric function.

Each method has a different shape and a different interpolation surface. RBF methods are mostly used for calculating smooth surfaces from many data points (ESRI, 2020). RBF method can also provide excellent interpolants for high-dimensional data sets of poorly distributed data points. The most important advantages of RBF method over other methods are as follows. This method can give clearer results in a shorter time in numerical solutions of partial differential equations than others. It can be applied very easily to higher-dimensional functions about interpolation process (Curtarelli et al 2015; Rocha, 2009).

To prepare noise maps, a high-resolution satellite image of the city was captured from Google Earth software (Google Earth 2018). This satellite image was digitized in the ArcGIS program. The noise values fixed on the digitized measurement points were processed by RBF (radial basis function) interpolation method in Geostatistical Analyst Tools Module of ArcGIS v10.4.1 software. The obtained data were overlapped with the World Imagery map base, and a total of 16 noise pollution maps were created. Flowchart of noise pollution mapping method is presented in Fig. 1. The names of measured points and their coordinates can be seen in supplementary dataset file as Table S1. The satellite image, 


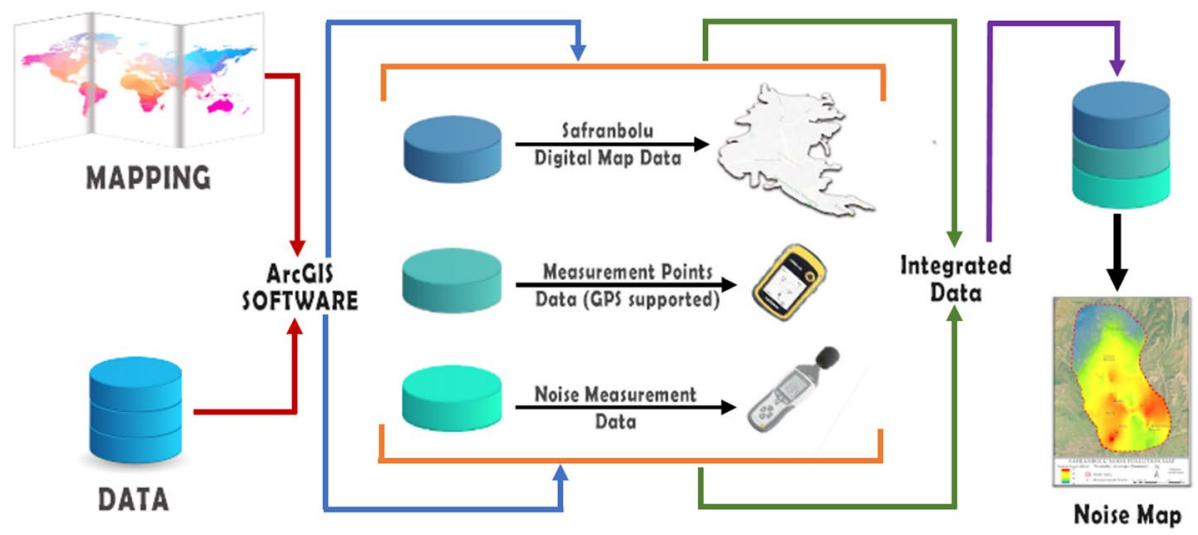

Fig. 1 Flowchart of noise pollution mapping method

which shows the measurement points, is shown in Fig. 2. Detailed map can be seen in Fig. $\mathrm{S} 1$ in supplementary dataset file.

The equivalent noise levels (Leq) were measured at 47 sample points in Safranbolu. The results that were obtained from measurements taken during weekday/weekend morning hours, lunch hours and evening hours in summer and winter seasons can be seen in Tables S3-S4-S5-S6 in the supplementary dataset file. The noise maps generated using the measured values in these tables are given in Fig. 5 for summer weekdays, in Fig. 6 for summer weekends and in Figs. 8 and 9 for the calculated average values, respectively. The data from winter season are delineated in Fig. 12 for winter weekdays, in Fig. 13 for winter weekends and in Figs. 15 and 16 for the average values. The abbreviations used in the tables can be seen in Table S2 in supplementary dataset file.

The distribution of the measurements which were made during weekdays at morning, lunchtime and evening hours throughout the summer season is shown in Fig. 3. It can be seen on the graph that the lowest values were at Point No. 30 (Çamtarla) and at 31 (Safranbolu City Forest) at noon and 34 (İnce Kaya Su Kemeri) at evening and that the highest noise measurements were obtained at the measuring point 12 (Terminal) during morning, afternoon and evening hours. At the measuring points No. 3, 9, 10, 11, 12, 14, 15, 16, 20, $21,22,37,40,42,43,45$ and 46, values above $65 \mathrm{dBA}$ (red line), which is the threshold value for starting to observe harmful physiological effects on humans (Table 1), were frequently observed. High stress levels, lack of concentration, hearing loss, tinnitus, sleep disturbances, hypertension and other harmful physiological reactions can be observed on the people that living near these locations with noise levels within the range of 65-90 dBA (Fig. 4).

The distribution of the measurements which were made during weekends at morning, lunchtime and evening hours throughout the summer season is shown in Fig. 4. The lowest values were recorded at 34 (Ince Kaya Su Kemeri) in the evening, while the highest noise levels were measured at 12 (Terminal) and at 20 (Eski Çarşı Meydan) at the lunchtimes. At the measuring points No. 11, 12, 14, 15, 16, 18, 19, 20, 21, 37, 40, 42, 43, 45 and 46, majority of the measured values were greater than $65 \mathrm{dBA}$ (Figs. 5, 6).

Average noise distribution measurements for summer weekdays and weekends $\left(\mathrm{L}_{\mathrm{MNE}}=\right.$ average value of morning, noon and evening measurements $)$ are shown in Fig. 7. The lowest average dBA values were estimated for 30 (Çamtarla) and 34 (İnce Kaya Su 


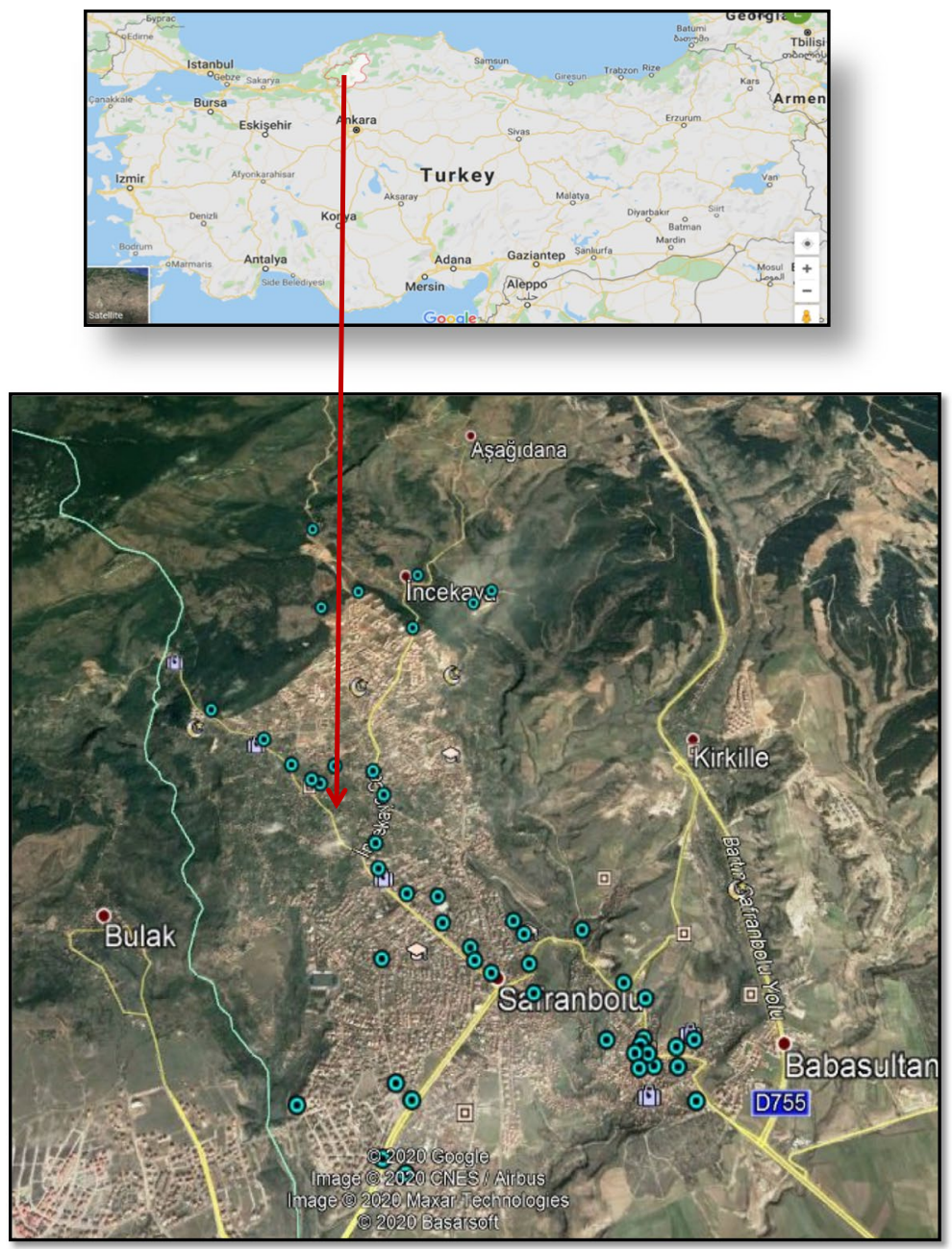

Fig. 2 Map and satellite image, which shows the measurement points (Google Earth 2018)

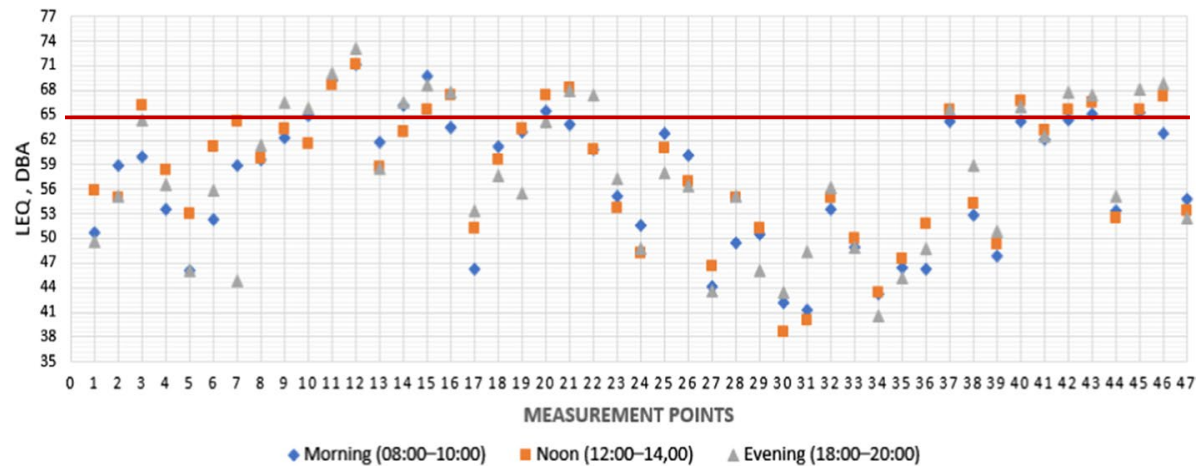

Fig. 3 Morning-noon-evening noise distribution in the summer season weekdays 


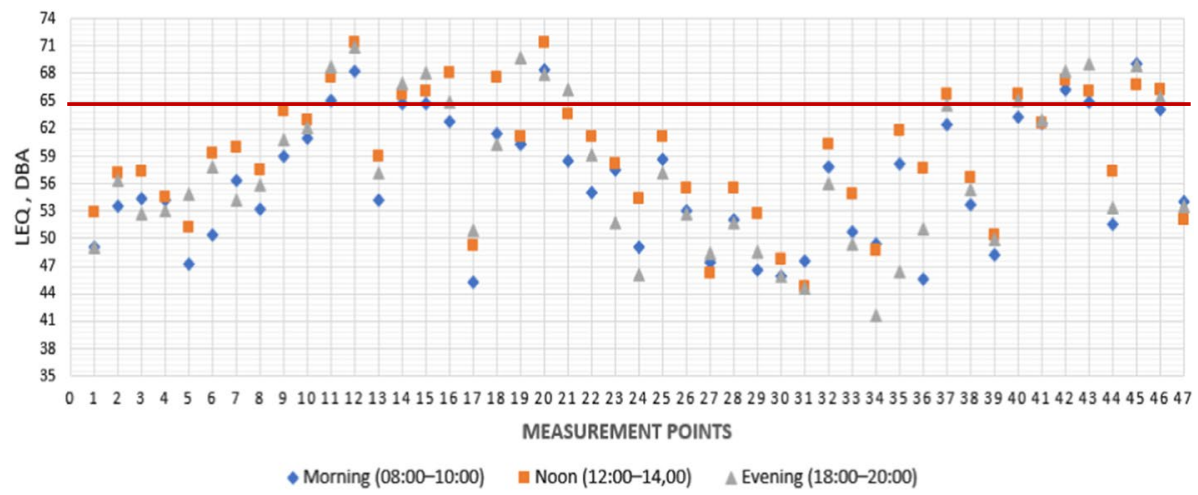

Fig. 4 Morning-noon-evening noise distribution in the summer season weekends
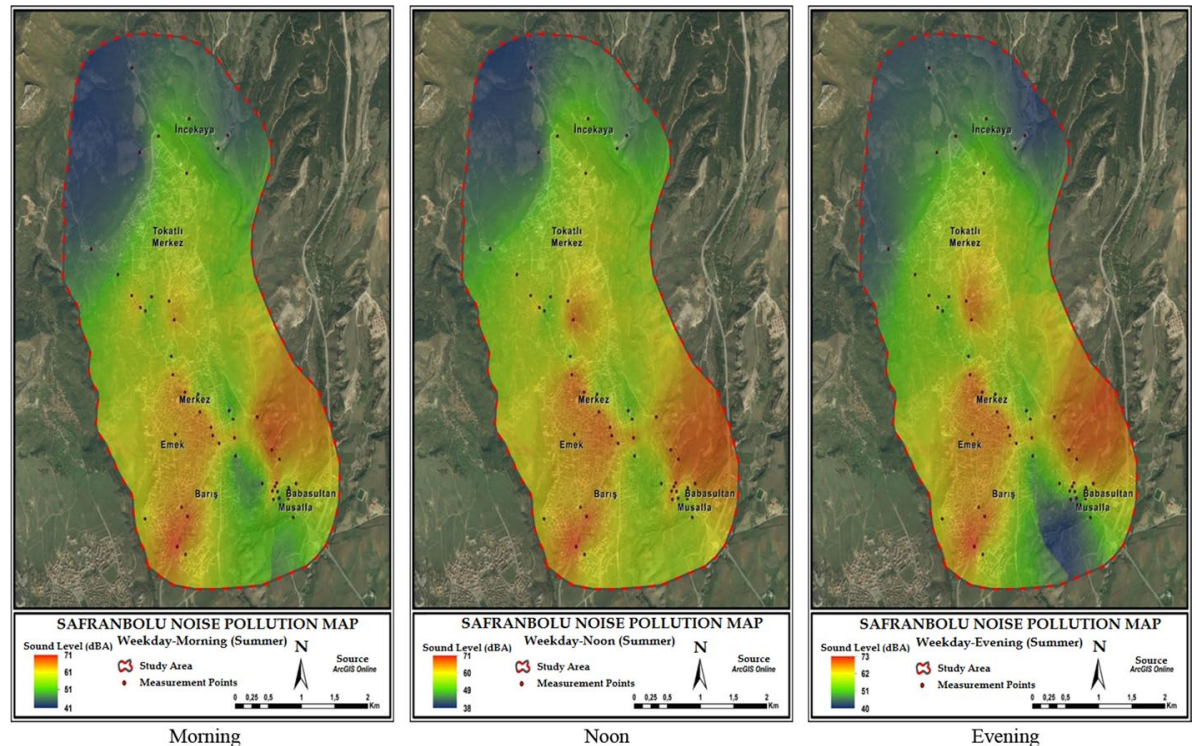

Fig. 5 Summer season weekdays morning-noon-evening noise measurement maps

Kemeri) on weekdays, while the highest average noise values were calculated for 12 (Terminal) on weekdays. At the measuring points No. 11, 12, 14, 15, 16, 19, 20, 21, 40, 42, 43, 45 and 46, calculated average values were above $65 \mathrm{dBA}$.

The noise pollution map, which is drawn using the calculated average noise values of the measurements taken during summer weekdays in Safranbolu, is given in Fig. 8. The noise pollution map, which is drawn using the calculated average noise values of the measurements taken during summer weekends in Safranbolu, is given in Fig. 9. On both maps the red-orange colored areas indicating higher noise levels on the map are the locations overlaps. The reason for the high level of noise in Merkez (Downtown of Safranbolu) and Emek Neighbourhoods is considered to be numerous restaurants, cafes, supermarkets and commercial other establishments located in these areas. The reason for the high level of noise in Barış Neighbourhood is the small industrial zone 


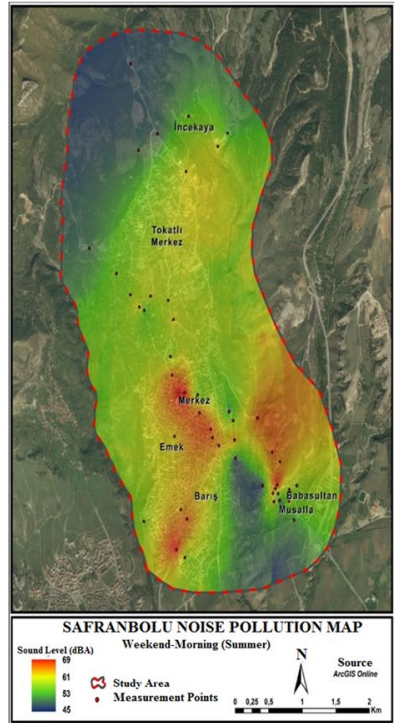

Morning

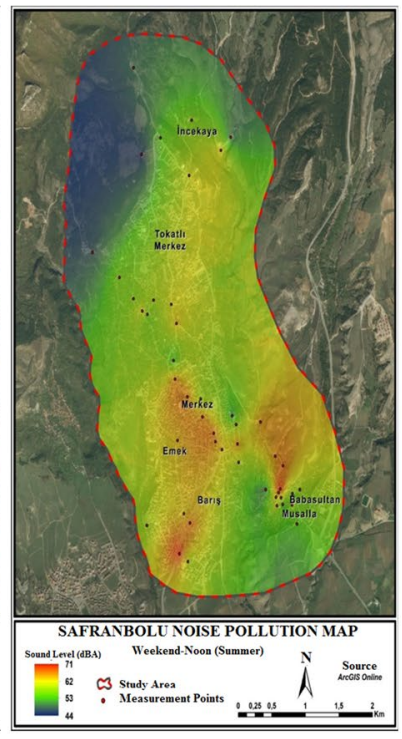

Noon

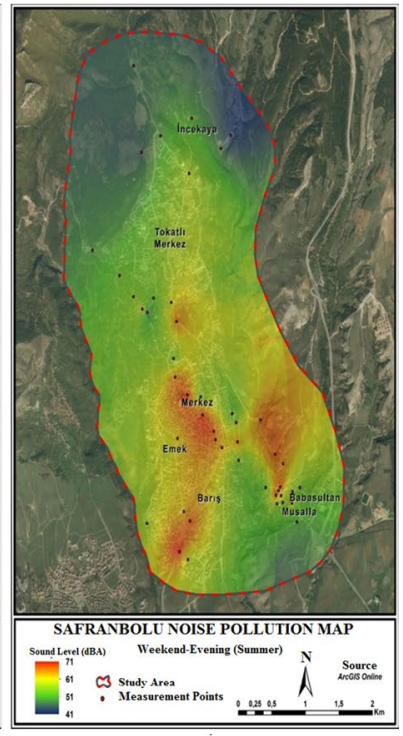

Evening

Fig. 6 Summer season weekend morning-noon-evening noise measurement maps

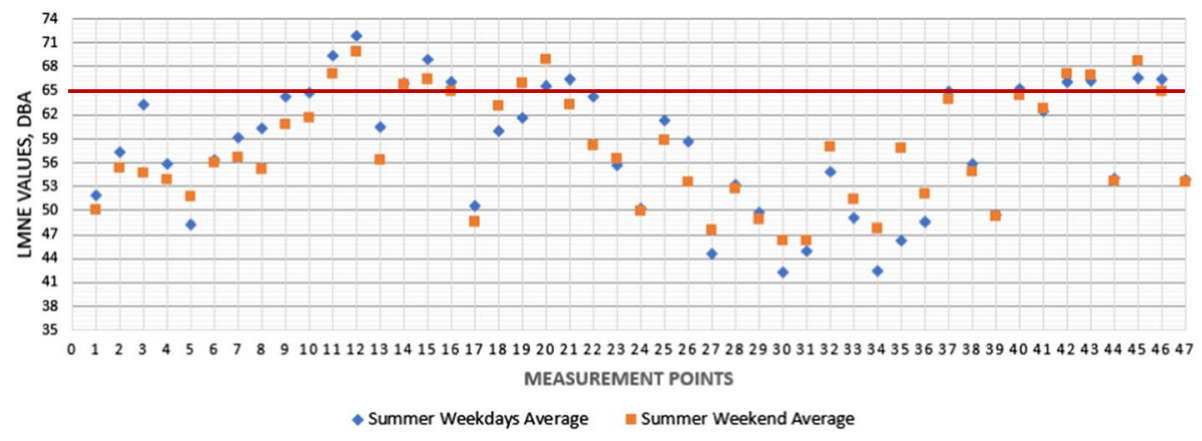

Fig. 7 Summer and weekend average noise distribution $\left(\mathrm{L}_{\mathrm{MNE}}\right)$

containing various workshops, autoshops and small-scaled steel mills; the intercity bus terminal is also located in this area. The other red-orange colored patch of land (near the southeast corner of the mapped area) is where the Eski Çarş1 (Old Town) and the connection point of Bartın highway is located. Old Town area is the main destinations for domestic and foreign visitors. Bartın highway is frequently used by people driving toward other popular touristic destinations, such as Amasra and İnkumu.

The distribution of the measurements which were made during weekdays at morning, lunchtime and evening hours throughout the winter season is shown in Fig. 10. The lowest values are recorded at 3 (Çamlıca Konak) at lunchtime and at 12 (Terminal), 22 (Cimbek Sokak) and 46 (Bağlar Saray) in the evening. The highest noise values were obtained at 3 (Terminal) at noon and evening hours. At the measuring points 3, 7, 9, $10,11,12,16,21,22,26,37,40,42,43,45$ and 46, measured values are above $65 \mathrm{dBA}$ 
Fig. 8 Summer season weekdays average noise pollution map

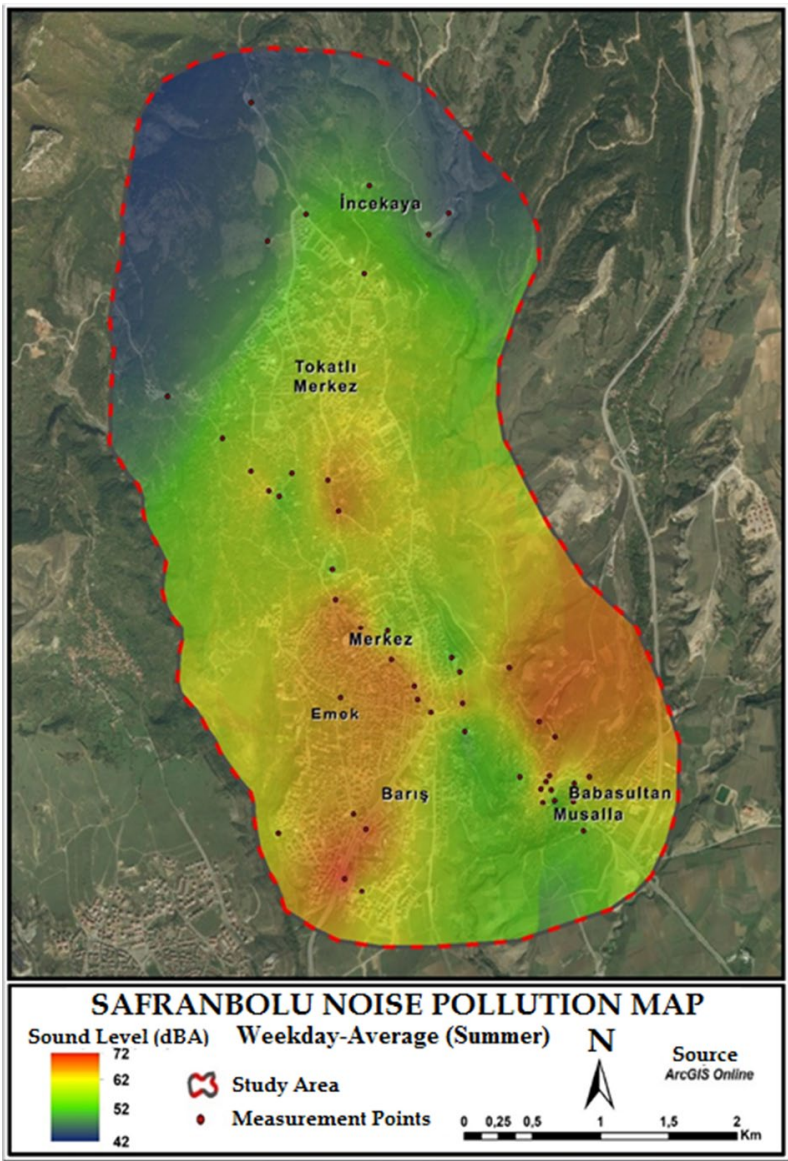

threshold (Table 1). Physiological reactions can be observed on the people that living in these areas.

The distribution of the measurements which were made during weekends at morning, lunchtime and evening hours throughout the winter season is shown in Fig. 11. The lowest values were at 29 (Sarı Çiçek Villas) and 30 (Çamtarla) in the morning, while the highest value was obtained at 45 (Telekom) at lunchtime hours. At the measuring points 11, 12, 37, $40,42,43,45$ and 46, most of the recorded values were above 65 dBA (Figs. 12, 13).

The average distribution of the measurements $\left(\mathrm{L}_{\mathrm{MNE}}=\right.$ morning, noon and evening average noise distribution) which were made during weekends and weekdays in winter season is shown in Fig. 14. The lowest values were recorded at 30 (Çamtarla) on both weekdays and weekends. The highest noise values were recorded at 3 (Çamlıca Konak) on weekends. At the measuring points 3,11, 12, 16, 21, 22, 37, 40, 42, 43, 45 and 46, most of the recorded values are above $65 \mathrm{dBA}$.

The noise pollution map obtained with the average noise values of the measurements taken during winter weekends in Safranbolu is given in Fig. 15. The noise pollution map obtained with the average noise values of the measurements taken during winter weekends in Safranbolu is given in Fig. 16. Comparing the results obtain during the winter and summer season, it is seen that areas with high noise levels mostly overlap. Only markedly 
Fig. 9 Summer season weekends average noise pollution map
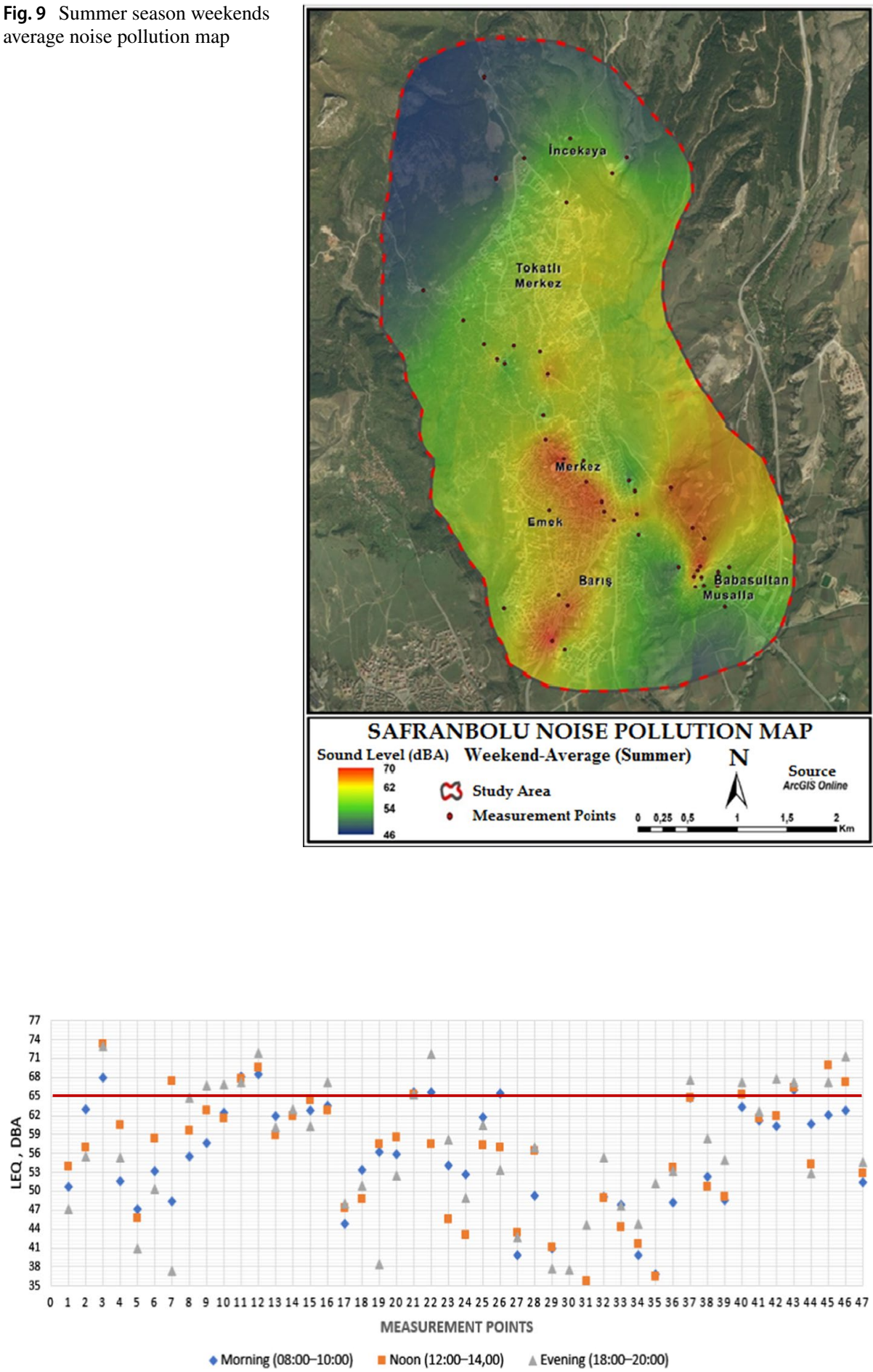

Fig. 10 Morning-noon-evening noise distribution in the winter season weekdays 


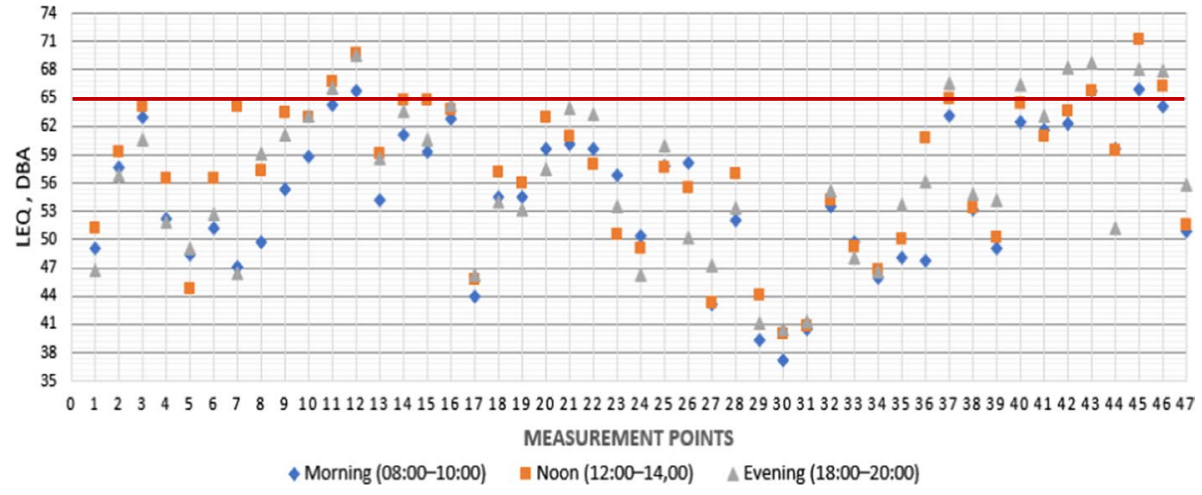

Fig. 11 Morning-noon-evening noise distribution in the winter season weekends

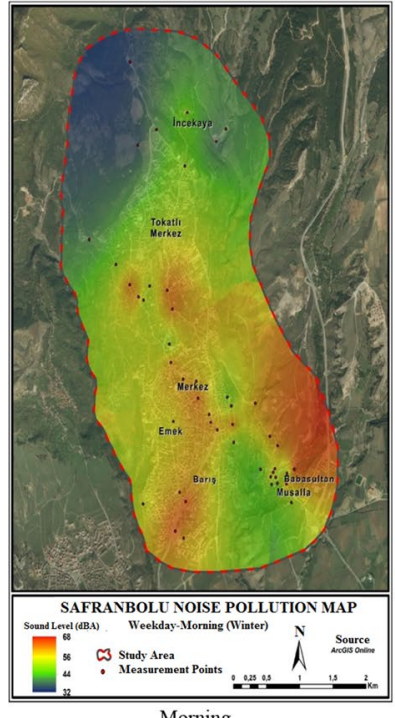

Morning

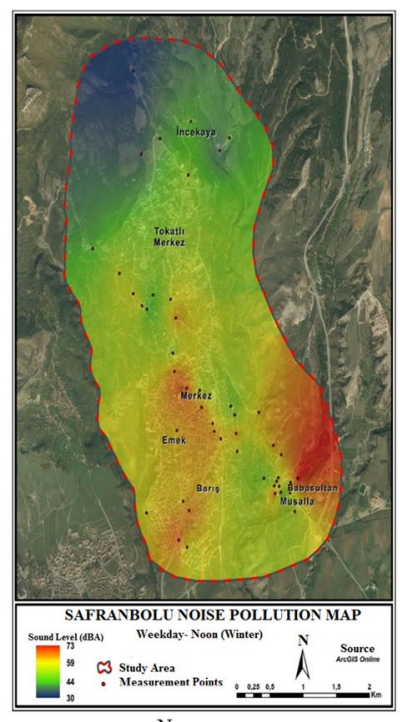

Noon

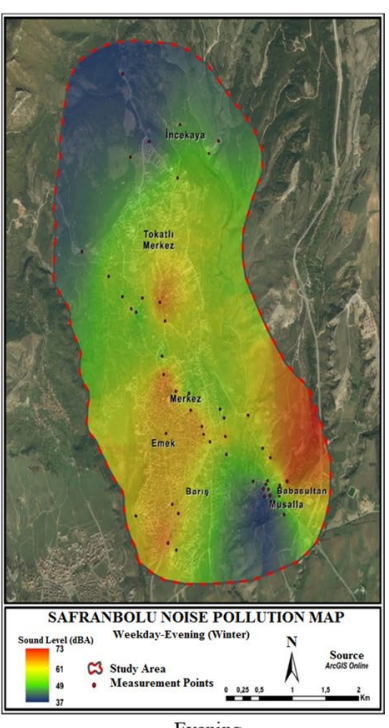

Evening

Fig. 12 Winter season weekday morning-noon-evening noise measurement maps

difference is that the noise level is slightly lower in Tokatlı and Incekaya villages because these two are less densely populated settlements and lower number of visitors during winter season.

\section{Results}

In the City of Safranbolu, 47 different measurement points have been chosen mostly near the main transportation routes and touristic areas, to determine and map the noise levels. The obtained results were compared to the limit values that are stated in Turkish Regulation on the Assessment and Management of Environmental Noise (Anonymous 2016). 


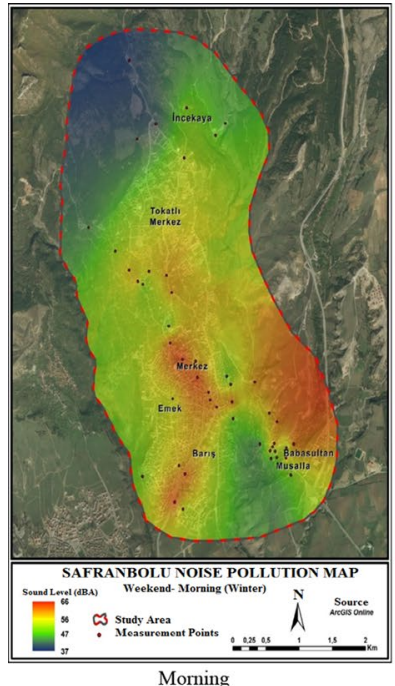

Morning

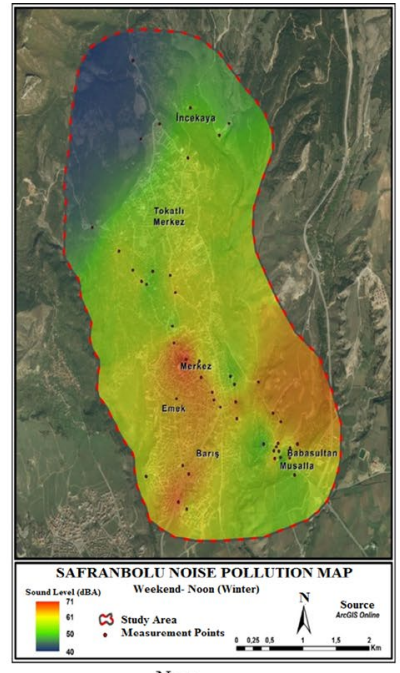

Noon

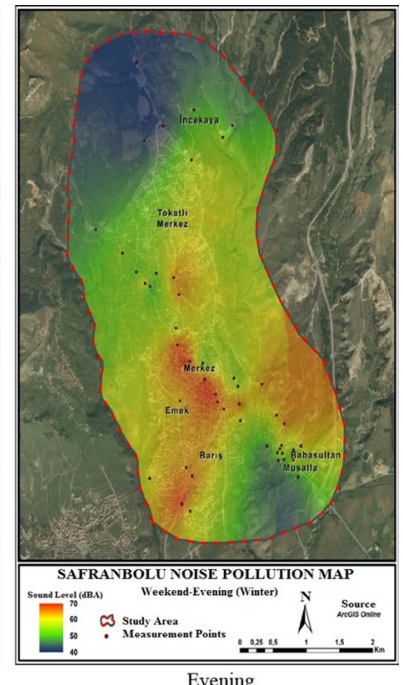

Evening

Fig. 13 Winter season weekends morning-noon-evening noise measurement maps

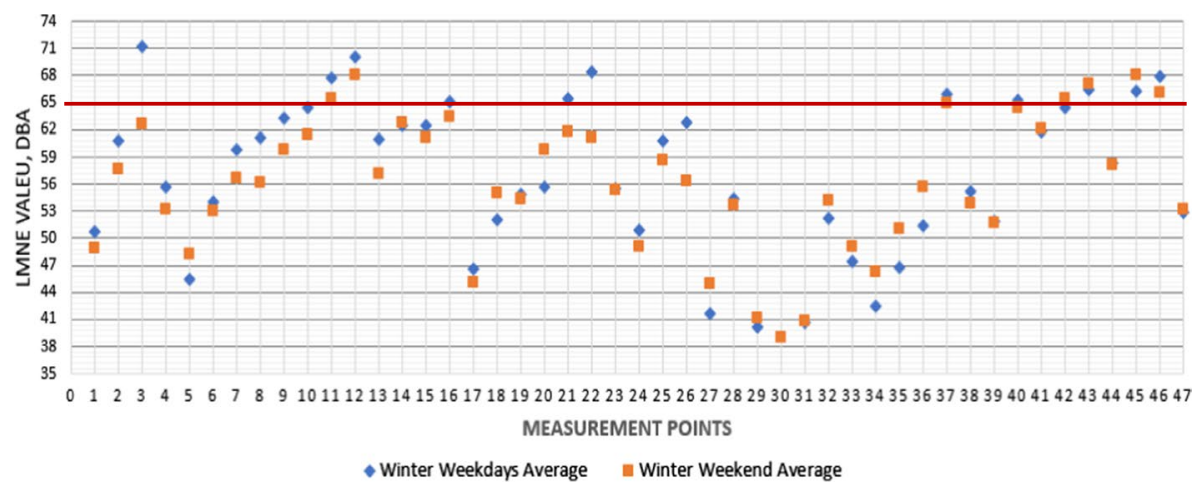

Fig. 14 Winter season, weekdays and weekend average noise distribution $\left(\mathrm{L}_{\mathrm{MNE}}\right)$

Type of text The limit value of $65 \mathrm{dBA}$ that is stated the "Regulation on the Assessment and Management of Environmental Noise" as a threshold for harmful health effect was exceeded at these points during the weekdays in winter: $71.20 \mathrm{dBA}$ at Çamlıca Konak, $70.20 \mathrm{dBA}$ at Terminal, 68.41 dBA at Cimbek Sokak, 67.99 dBA at Bağlar Saray, 67.82 $\mathrm{dBA}$ at Sanayi Girişi, $66.51 \mathrm{dBA}$ at MADO, $66.23 \mathrm{dBA}$ at Telekom, $65.96 \mathrm{dBA}$ at Eski Çarşı Girişi, $65.46 \mathrm{dBA}$ at Merhabası Yanında, $65.34 \mathrm{dBA}$ at Japon Dostluk Anıtı and 65.04 at dBA Kalealtı İlkokulu.

The limit value was exceeded at these points during the weekends in winter: $68.16 \mathrm{dBA}$ at Terminal, $68.03 \mathrm{dBA}$ at Telekom, 67.04 dBA at MADO, $66.10 \mathrm{dBA}$ at Bağlar Saray, 65.39 dBA at Sanayi Girişi and 65.37 dBA at Atamerkez.

The limit value was exceeded at these points during the weekdays in summer: 71.91 dBA at Terminal, $69.44 \mathrm{dBA}$ at Sanayi Giriş, $68.89 \mathrm{dBA}$ at Havuzlu Asmazlar Konağı, 66.53 dBA at Telekom, 66.47 dBA at Merhabası, 66.39 dBA at Bağlar Saray, 66.29 dBA 
Fig. 15 Winter season weekdays average noise pollution map

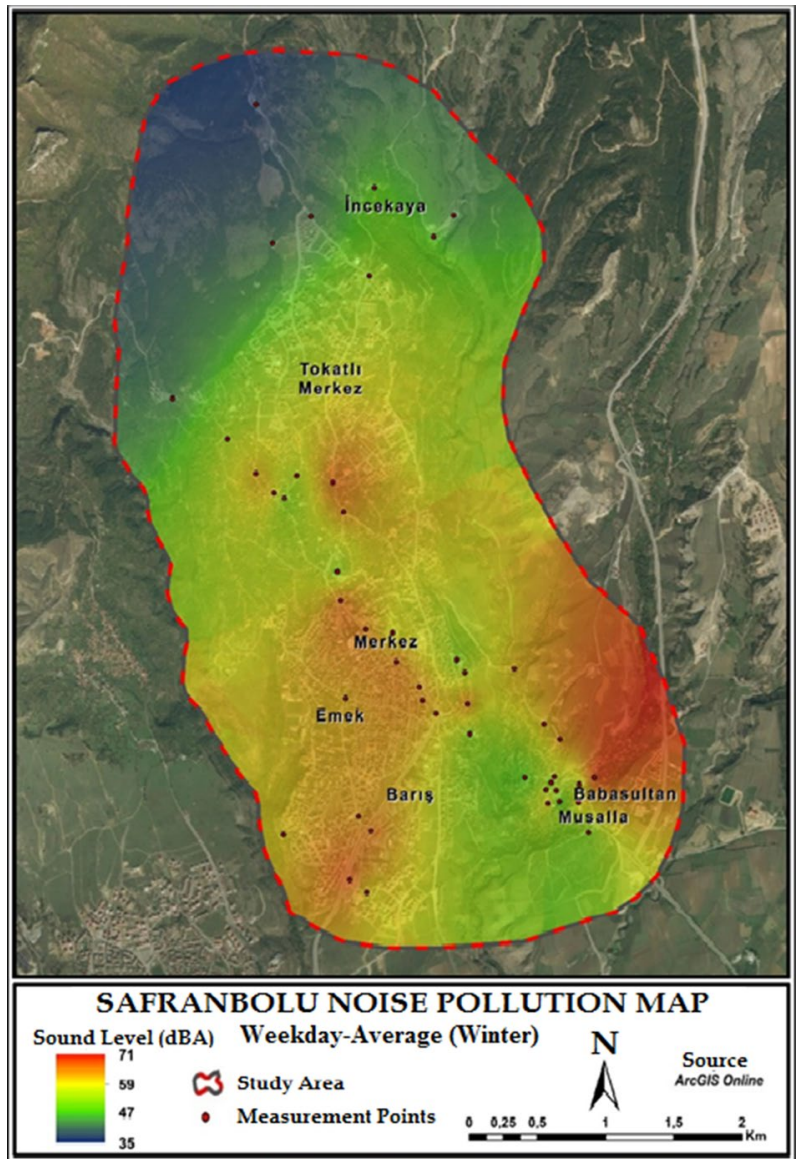

at MADO, $66.13 \mathrm{dBA}$ at Kalealtı İlkokulu, 66.02 dBA at Atamerkez AVM, $65.94 \mathrm{dBA}$ at İsmet Paşa Mahallesi, $65.58 \mathrm{dBA}$ at Eski Çarşı Meydan and 65.31 at dBA Japon Dostluk Aniti.

The limit value was exceeded at these points during the weekends in summer: 69.89 dBA at Terminal, $68.97 \mathrm{dBA}$ at Eski Çarşı Meydan, 68.76 dBA at Telekom, $67.15 \mathrm{dBA}$ at Atamerkez AVM, 67.08 dBA at Sanayi Girişi, 66.89 dBA at MADO, 66.36 dBA at Havuzlu Asmazlar Konağı, $65.87 \mathrm{dBA}$ at Arasta, $65.83 \mathrm{dBA}$ at İsmet Paşa Mahallesi and 65.00 $\mathrm{dBA}$ at Bağlar Saray.

\section{Discussion}

Recently facilitated faculties and vocational schools that are affiliated units of Karabük University are in the center of the city. The literature on the subject suggests that the large number of students attending these schools may cause a spike in noise levels. In a similar study conducted on the campus of Suleyman Demirel University (Isparta, Turkey), 96 different points in the campus were measured and the average noise value was measured at $53.16 \mathrm{dBA}$. The highest measured value was $76.50 \mathrm{dBA}$, and the lowest measured value 
Fig. 16 Winter season weekend average noise pollution map

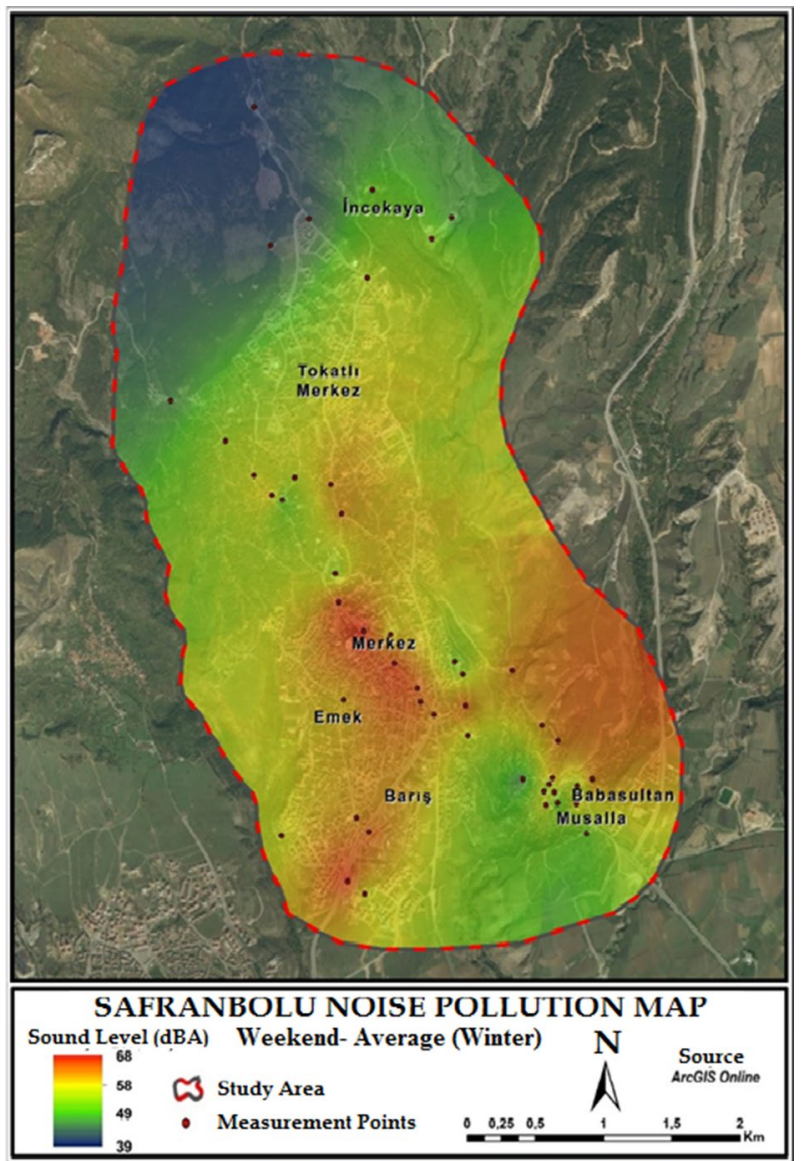

was $34.50 \mathrm{dBA}$. Processing the values obtained from the measurements, the noise maps of the campus were prepared in Morova et al. (2010). In another study, the measurement results from 7 different points in Çukurova University (Adana, Turkey) were between 70 and $75 \mathrm{dBA}$ in the morning; between 45 and $50 \mathrm{dBA}$ during evening hours; and between 30 and $35 \mathrm{dBA}$ at night (Bicakci and Selek 2012). Also, in a different study carried out on Kanuni Campus of Karadeniz Technical University (Trabzon, Turkey), the noise levels were higher level than the limit values, and it was suggested to use a two-layered window system instead of single-layered system (Kavraz, 2015). Additionally, Karvaz suggested usage of multilayers and isolation layers on the wall sections.

All the historical streets in the Old Town of Safranbolu are cobblestone paved. This type of pavement causes 2-3 times higher noise levels compared to flat asphalt pavements (Bozkurt and Selek 2018). The Old Town area in Düzce Province, which is structured similar to Safranbolu Old Town, and the noise levels in the pedestrian areas were highest in the summer and the lowest in the winter season (Yerli, 2016). Observations support that motor vehicle traffic - although it is slower-in the Old Town creates a higher level of noise pollution compared to other parts of the town.

The usage of inappropriate exhaust silencer units in motor vehicles and negligence of necessary maintenance of the vehicles causes very high levels of noise in the district 
centers (Yilmaz and Ozer 2005; Cueto et al. 2017; Morley et al. 2015). Also, excessive honking on the roads increases the noise levels. The main reasons for these are the lack of a properly functioning traffic signaling system and traffic density in the urban areas (Bilgen, 2017; Sahin et al. 2016). The highest noise levels due to traffic were detected at the morning hours rather than at noon and evening hours (Aydin et al. 2005).

During this study, also a survey was conducted on noise pollution involving 500 people in order to determine the awareness level of the inhabitants and visitors about the issue. According to responses to the survey, 442 people considered noise as pollution; 38 people did not express noise as a pollution category; and 20 people did not comment about this issue. A total of 148 people reported that they have submitted complaints about the noise pollution, and 352 people did not act on this issue. Of the 148 people who filed a complaint, 90 of them made it over the telephone; 50 of them made faceto-face complaints; 20 of them made it through a written petition to the authorities; 8 of them made it by sending an e-mail to the authorities; 2 of them made it through the press; and 5 of them used other channels to convey their complaints.

In this study, the interpretation of the data implied that the highest contribution to the noise pollution in the City of Safranbolu is most likely generated by tourist population density. The students form a large portion of the local population during winter months, but most of the students are absent during summer. Despite students' absence, markedly higher noise levels were measured in the summer season compared to the winter season. This can be explained by a much greater number of visiting tourists compare to the absent students.

Most of the Safranbolu District Area is covered by "protected areas" under the protection of strict legislations prohibiting new construction, since the old town area is on the UNESCO World Heritage Center list. Accordingly, structural solutions to abate pollution from existing noise sources are not possible in most cases (such as installation of concrete and metal barriers). Instead, solutions to avoid noise should be natural and/or with minimum interference to the original architecture. These can be listed as: green barriers composed of plants and trees, sound insulation for important buildings, adopting contemporary urban planning techniques for creating new urban areas, noise reduction measures at the source of fixed noise sources and increasing awareness and sensibility of the local people.

Some case studies in the literature on natural solutions that may be suitable for environmental noise pollution control. Architectural landscape solutions can be considered to implement, such as forming noise barriers out of plants, green roofs, green walls etc. Plants can accomplish different forms of noise reduction through different parts in their structure. Sound can be reflected from or absorbed on the trunk, branches and leaves of the plants at different rates (Dimitrijević 2017). It was reported that the following many plants can be used as barriers to reduce noise level by $\sim$ dBA: Hedera helix, Rubus fruticosus, Polygonum auberti, Parthenocissus quinquefolia, Viburnum rhytidophyllum, Acer pseudoplatanus, Betula verrucosa, Cornus alba, Corylus avellana, Crataegus monogyna Forsythia intermedia, Lonicera tatarica, Berberis thunbergia, Philadelphus coronarius, Populus tremula, Pyracantha coccinea, Ribes sp, Sambucus nigra, Sorbaria sorbifolia, Syringa vulgaris, Tilia cordata, Tilia platyphylla, Viburnum lantana, Cheamacyparis lawsoniana, Cotoneaster dammeri,Cupressus sempervirens leylandii, Cupressocyparis leylandii, Cupressus arizonica, Cupressus macrocarpa, Cupressus sempervirens cv. Glauca, Juniperus excelsa, Juniperus chinensis cv. Stricta, Juniperus horizontalis, Juniperus oxycedrus, Pinus mugo, Pinus mugo cv. Nigra, Pinus pinaster, Pinus radiata, Pinus silvestris and Thuja orientalis, Photinia fraseri, Photinia serru- lata, Spirea vanhouetti Nerium indicum, Oligostachyum lubricum, Cedrus deodara, Viburnum odoratissimum. (Erdogan and 
Yazgan 2007; Ozer et al. 2008; Fan et al. 2010; Onder and Kocbeker 2012; Ropus et al. 2013; Ferrini et al. 2020; Paul et al. 2020).

The measures that can be taken by the local government are as follows (Environmental Noise Directive 2002; Maffei and Masullo 2014; Mahler and Bohli 2015; Penton 2016; Dimitrijević 2017; Jacyna et al. 2017; Jena et al. 2018; Boren 2019; Ferrini et al. 2020; EU-European Commission 2020a, b):

- Ensuring that the new buildings to be built in the region comply with the "Protection of Buildings Against Noise" regulation.

- Replacing traditional asphalt pavement with more efficient alternative options (this is more effective than other options in reducing traffic noise),

- Increasing the number of noise-protected pedestrian zones by restricting vehicle traffic and unloading at certain times of the day,

- Increasing cycling paths,

- Regular maintenance of municipal vehicles,

- In the long term, preferring procurement of hybrid or electric vehicles for municipal services,

- In the long term, switching to hybrid or electric public transport vehicles.

- Applying green solutions to prevent environmental noise pollution (such as green living walls, green roofs, natural barriers made from suitable trees, plants, ivy and bush types)

- Applying natural solutions involving use of eco-friendly insolation materials to prevent environmental noise pollution (such as jute, sheep wool, rice paddy, sugar cane, coconut fibers, husk and rice straw types)

- Use of soundproof construction materials,

- Noise isolation certification for residential and commercial buildings.

- Activities to create environmental noise awareness in the society

Environmental noise pollution management and control can be successfully carried out by considering the above-mentioned measures and recommendations. Otherwise, environmental noise will emerge as a major problem in regions with rapidly growing populations and tourism potential, like Safranbolu.

Supplementary Information The online version contains supplementary material available at https://doi. org/10.1007/s10668-021-01303-5.

Acknowledgements This study was supported by Karabük University with the Project Number KBÜBAP-17-YL-267.

\section{References}

Anonymous. (1996). Fighting noise: Strengthening noise abatement policies. OECD.

Anonymous (2016). Regulation on Assessment and Management of Environmental Noise, Official Gazette of the Republic of Turkey, Official Gazette No. 29606, 27 January 2016, Ankara.

Adhikary, P. P., \& Dash, C. J. (2017). Comparison of deterministic and stochastic methods to predict spatial variation of groundwater depth. Applied Water Science, 7(1), 339-348.

Arseni, M., Voiculescu, M., Georgescu, L. P., Iticescu, C., \& Rosu, A. (2019). Testing different interpolation methods based on single beam echosounder river surveying. Case study: Siret River. ISPRS International Journal of Geo-Information, 8(11), 507. 
Aydın, M. E., Corumluoglu, O., Sari, S., \& ve Ozcan, S. (2005). Using GIS and GPS technologies of Konya City vehicle traffic noise levels mapping, Selcuk University Journal of Engineering and Architecture Faculty, Konya, pp. 7-17.

Bermúdez, F. M., Laxe, F. G., \& Aguayo-Lorenzo, E. (2019). Port sustainability in Spain: The case of noise. Environment, 1, 18.

Bhunia, G. S., Shit, P. K., \& Maiti, R. (2018). Comparison of GIS-based interpolation methods for spatial distribution of soil organic carbon (SOC). Journal of the Saudi Society of Agricultural Sciences, 17, 114-126. https://doi.org/10.1016/j.jssas.2016.02.001

Bicakci, T. \& ve Selek, Z. (2012). Traffic noise noise maps and Çukurova University Campus case, Cukurova University Journal of Science and Engineering, Adana, pp. 15-125.

Bilgen, İ. (2017). Noise levels measurement and noise mapping in traffic in Nevsehir Province, Ms. Thesis, Nevşehir Hacı Bektaş Veli University Institute of Science, Nevşehir.

Borén, S. (2019). Electric buses' sustainability effects, noise, energy use, and costs. International Journal of Sustainable Transportation, 3, 1-16.

Bozkurt, Z., \& Ve Selek, Z. (2018). Investigation of the contribution of different road coatings to environmental noise levels in highway transportation: The case of Adana. Politeknik Journal, 1, 63.

Cueto, J. L., Petrovici, A. M., Hernández, R., \& Fernández, F. (2017). Analysis of the impact of bus signal priority on urban noise. Acta Acustica United Acustica, 103(4), 561-573. https://doi.org/10.3813/ AAA.919085

Curtarelli, M., Leão, J., Ogashawara, I., Lorenzzetti, J., \& Stech, J. (2015). Assessment of spatial interpolation methods to map the bathymetry of an Amazonian hydroelectric reservoir to aid in decision making for water management. ISPRS International Journal of Geo-Information, 4(1), 220-235.

Dimitrijević, D., Živković, P., Dobrnjac, M., \& Latinović, T. (2017). Noise pollution reduction and control provided by Green living systems in urban areas. Innovations, 5(3), 133-136.

Directive, E. N. (2002). Directive 2002/49/EC of the European Parliament and of the Council of 25 June 2002 relating to the assessment and management of environmental noise. Official Journal Level, 189, 12-26.

Erdogan, E., \& Ve Yazgan, M. E. (2007). Landscape architecture studies in reducing traffic noise problem in

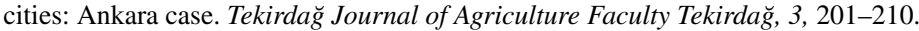

ESRI, (2020). Deterministic methods-RBF, Retrieved September 1, 2020. http://webhelp.esri.com/arcgi sdesktop/9.2/index.cfm?TopicName=How_Radial_Basis_Functions_(RBF)_work.

EU-European Commission, (2020). Guidelines for Road Traffic Noise Abatement, Retrieved from https://ec.europa.eu/environment/life/project/Projects/index.cfm?fuseaction=home.showF ile\&rep=file\&fil=SMILE_guidelines_noise_en.pdf.

EU-European Commission, (2020). Urban greening reduces noise pollution, Retrieved from https://ec.europ a.eu/environment/integration/research/newsalert/pdf/328na6_en.pdf.

Fan, Y., Zhiyi, B., Zhujun, Z., \& Jiani, L. (2010). The investigation of noise attenuation by plants and the corresponding noise-reducing spectrum. Journal of Environmental Health, 72(8), 8-15.

Farooqi, Z. U. R., Nasir, M. S., Nasir, A., Zeeshan, N., Ayub, I., Rashid, H., Qamar, M. U., Sarwar, A., \& Akram, M. A. (2017). Evaluation and analysis of traffic noise in different zones of Faisalabad-an industrial city of Pakistan. Geology, Ecology, and Landscapes, 1(4), 232-240. https://doi. org/10.1080/24749508.2017.1389454

Ferrini, F., Fini, A., Mori, J., \& Gori, A. (2020). Role of vegetation as a mitigating factor in the urban context. Sustainability, 12(10), 4247.

Garg, N., Sinha, A. K., Gandhi, R. M., Bhardwaj, A., \& Akolkar, B. (2017). Impact of diwali celebrations on environmental noise pollution in India. Acoust Australia, 45(1), 101-117. https://doi.org/10.1007/ s40857-017-0081-z

Google Map (2020). [Safranbolu District Digital Map], Retrieved January 5, 2020, from https:// www.google.com.tr/maps/place/Safranbolu,+Karab\%C3\%BCk/@ 41.2592819,32.6624201,14z/ data $=$ !4m5!3m4!1s0x409caac51abbad83:0x6b7db3ac7a87e93d!8m2!3d41.249306!4d32.683128.

Google Earth (2018). [Safranbolu District High Resolution Satellite Image], Retrieved January 5, 2018, from https://earth.google.com/web/search/safranbolu/@41.25745976,32.67739529,551.76662 014a,8747.34615105d,35y,-0h,0t,0r/data=CnUaSxJFCiUweDQwOWNhYWM1MWFiYmFkODM 6MHg2YjdkYjNhYzdhODdlOTNkGS1ZTkLpn0RAIa59Ab1wV0BAKgpzYWZyYW5ib2x1GAIgA SImCiQJttnFuEI_OUAR22ttF_UUMsAZxpkSAunQXkAhj0glK6c1YcA.

Gupta, A., Gupta, A., Jain, K., \& Gupta, S. (2018). Noise pollution and impact on children health. The Indian Journal of Pediatrics, 85(4), 300-306.

Imamoglu, M. Z., \& Sertel, E. (2016). Analysis of different interpolation methods for soil moisture mapping using field measurements and remotely sensed data. International Journal of Environment and Geoinformatics, 3(3), 11-25. 
Jacyna, M., Wasiak, M., Lewczuk, K., \& Karoń, G. (2017). Noise and environmental pollution from transport: decisive problems in developing ecologically efficient transport systems. Journal of Vibroengineering, 19(7), 5639-5655.

Jena, B. P., Jagdev, A., Satapathy, S., Nayak, B. B., Patel, S., \& Mohapatra, T. K. (2018). An Investigation on noise reduction by natural acoustic materials. Materials Today: Proceedings, 5(9), 19237-19241.

Kalawapudi, K., Singh, T., Dey, J., Vijay, R., \& Kumar, R. (2020). Noise pollution in Mumbai Metropolitan Region (MMR): An emerging environmental threat. Environmental Monitoring and Assessment, 192(2), 152.

Karabük Provincial Directorate of Environment and Forestry (2008). Karabük province Environment Status Report, Karabuk, Turkey.

Karabük Provincial Directorate of Environment and Forestry (2017). Karabük province Environment Status Report, Karabuk, Turkey.

Karakus, B. C., \& Yıldız, S. (2020). Evaluation of noise pollution level from traffic for Sivas city using GIS-based noise indexes. Cumhuriyet Science Journal, 41(11), 176-218.

Kavraz, M. (2015). Evaluation of noise levels in terms of interiors-KTU Kanuni Campus. SDU-Journal of Engineering Sciences and Design Isparta, 2, 597-601.

Kephalopoulos, S., Paviotti, M., Anfosso-Lédée, F., Maercke, D. V., Shilton, S., \& Jones, N. (2014). Advances in the development of common noise assessment methods in Europe: The CNOSSOS-EU framework for strategic environmental noise mapping. Science of the Total Environment, 482-483, 400-410. https://doi.org/10.1016/j.scitotenv.2014.02.031

Khodaei, M., Nasiri, P., Monazam, E., Pour, M., \& Mirjalili, N. (2009). Evaluation of noise pollution and traffic noise index (TNI) in the main streets of Yazd. In 3rd Conference of environmental engineering

Kumar, A., Kumar, P., Mishra, R. K., \& Shukla, A. (2018). Study of air and noise pollution in mega cities of India. In Environmental pollution (pp. 77-84). Springer, Singapore.

Li, Q., Qiao, F., \& Yu, L. (2016). Impacts of pavement types on in-vehicle noise and human health. Journal of the Air and Waste Management Association, 66(1), 87-96.

Maffei, L., \& Masullo, M. (2014). Electric vehicles and urban noise control policies. Archives of Acoustics, 39(3), 333-341.

Mahler, N., \& Bogli, H. (2015). Harmonizing noise abatement and urban development. Science, 3, 10.

Majidi, F., \& Khosravi, Y. (2016). Noise pollution evaluation of City Center of Zanjan by geographic information system (GIS). Iranian Journal of Health and Environment, 9(1), 91-102.

Mehdi, M. R., Arsalan, M. H., Gazder, U., Kim, M., Seong, J. C., Namdeo, A., \& Chang, S. I. (2018). Who is the bigger culprit? Studying impacts of traffic and land use on noise levels in CBD area of Karachi, Pakistan. Environment, Development and Sustainability, 20(3), 1421-1438.

Mongillo, M. (2011). Choosing basis functions and shape parameters for radial basis function methods. SIAM Undergraduate Research Online, 4(190-209), 2-6.

Morel, J., Marquis-Favre, C., \& Gille, L. A. (2016). Noise annoyance assessment of various urban road vehicle pass-by noises in isolation and combined with industrial noise: a laboratory study. Applied Acoustics, 10(1), 47-57. https://doi.org/10.1016/j.apacoust.2015.07.017

Morley, D. W., Hoogh, K., Fecht, D., Fabbri, F., Bell, M., Goodman, P. S., Elliott, P., Hodgson, S., Hanwell, A. L., \& Gulliver, J. (2015). International scale implementation of the CNOSSOS-EU road traffic noise prediction model for epidemiological studies. Environmental Pollution, 206, 332-341. https://doi.org/10.1016/j.envpol.2015.07.031

Morova, N., Sener, E., Terzi, S., Beyhan, M., \& Ve Harman, B. İ. (2010). Preparation of noise maps of Süleyman Demirel University Campus with geographic information systems. SDU Journal of Institute of Science Isparta, 3, 271-278.

Onder, S., \& Kocbeker, Z. (2012). Importance of the green belts to reduce noise pollution and determination of roadside noise reduction effectiveness of bushes in Konya, Turkey. International Journal of Agricultural and Biosystems Engineering, 6(6), 373-376.

Ozer, S., Irmak, M. A., \& Yilmaz, H. (2008). Determination of roadside noise reduction effectiveness of Pinus sylvestris L. and Populus nigra L. in Erzurum Turkey. Environmental Monitoring and Assessment, 144(1-3), 191-197.

Ozler A. (2020). Safranbolu hosted 6 times more of its population. In The Shadow of Covid-19, Anadolu News Aganecy (AA)

Oguntunde, P. E., Okagbue, H. I., Oguntunde, O. A., \& Odetunmibi, O. O. (2019). A study of noise pollution measurements and possible effects on public health in Ota metropolis, Nigeria. Open Access Macedonian Journal of Medical Sciences, 7(8), 1391-1395. https://doi.org/10.3889/oamjms.2019.234 
Paull, N. J., Krix, D., Torpy, F. R., \& Irga, P. J. (2020). Can green walls reduce outdoor ambient particulate matter, noise pollution and temperature? International Journal of Environmental Research and Public Health, 17(14), 5084.

Penton, S. (2016). Effectiveness of Noise Reducing Asphalt Pavements. Canadian Acoustics, 44(3).

Rafael, S. S., Fortes-Garrido, J. C., \& Bolívar, J. P. (2015). Characterization and evaluation of noise pollution in a tourist coastal town with an adjacent nature reserve. Applied Acoustics, 95, 70-76. https://doi. org/10.1016/j.apacoust.2015.02.004

Republic of Turkey Minister of Culture and Tourism, (2019). Provincial tourist statistics-Safranbolu, https:// safranboluturizmdanismaburosu.ktb.gov.tr/TR-231191/turist-istatistik-verileri.html, Accessed 15 April 2019.

Rocha, H. (2009). On the selection of the most adequate radial basis function. Applied Mathematical Modelling, 33(3), 1573-1583.

Ropus, I., Alar, V., \& Runje, B. (2013). Adaptive noise reduction system. Interdisciplinary Description of Complex Systems: INDECS, 11(1), 153-160.

Sahin, K., Bagci, H. R., \& Sari, E. (2016). Traffic polluted noise pollution in settlement areas on the intercity road route (Havza-Samsun Case), studies of the Ottoman Domain Press, Samsun, pp. 19-31.

Singh, D., Kumari, N., \& Sharma, P. (2018). A review of adverse effects of road traffic noise on human health. Fluctuation and Noise Letters, 17(01), 1830001.

TUIK (2019), Address Based Census, Turkish Statistical Institute. http://www.tuik.gov.tr/UstMe nu.do?metod=temelist. Accessed 1 April 2019.

Vladimir, M., \& Madalina, C. (2019). Optimizing urban landscapes in regard to noise pollution. Procedia Manufacturing, 32, 161-166.

Yerli, O. (2016). Investigation of noise differences of Pedestrian regions in Duzce City. Kastamonu University Forestry Journal, 2(225), 238.

Yilmaz, H., \& Ozer, S. (2005). Evaluation and analysis of environmental noise pollution in the city of Erzurum-Turkey. International Journal of Environment and Pollution, 23(4), 438-448. https://doi. org/10.1504/IJEP.2005.007606

Publisher's Note Springer Nature remains neutral with regard to jurisdictional claims in published maps and institutional affiliations.

\section{Authors and Affiliations}

\section{Ertugrul Esmeray $^{1}$ D $\cdot$ Sercan Eren ${ }^{1}$}

Ertugrul Esmeray

eesmeray@karabuk.edu.tr

1 Civil \& Environmental Engineering Department, Engineering Faculty, Karabuk University, Room: 441 Campus, Karabuk, Turkey 